\title{
Sleeping position for infants and cot death in the Netherlands 1985-91
}

\author{
Guus A de Jonge, Ruud J F Burgmeijer, Adèle C Engelberts, Jan Hoogenboezem, \\ Pieter J Kostense, Arwen J Sprij
}

\author{
Oegstgeest, The \\ Netherlands \\ $\mathrm{G}$ A de Jonge \\ National Association \\ for Home Care, \\ 1986 to 0.44 in 1991; the real decrease of \\ sudden unexpected death in infancy, \\ however, is greater. \\ (Arch Dis Child 1993; 69: 660-663)
}

Department of Child

Health Care, Bunnik

R J F Burgmeijer

Department of

Paediatrics, Free

University,

Amsterdam

A C Engelberts

Netherlands Central Bureau of Statistics, Voorburg

J Hoogenboezem

Department of Epidemiology and Biostatistics, Free

University,

Amsterdam

P J Kostense

Department of Paediatrics, Leiden University

A J Sprij

Correspondence to: Dr G A de Jonge, Prins Bernhardlaan 50, $2341 \mathrm{KL}$ Oegstgeest, The Oegstgeest,

Accepted 27 July 1993

\begin{abstract}
Until the early 1970s the traditional sleeping position for Dutch infants was not prone. After a much publicised lecture in October 1987 on the possible relation between sleeping prone and cot death, the fairly new habit of placing infants prone is being replaced by more traditional positions. The decrease in the prevalence of the prone sleeping position has been documented in six studies. Since 1987 the incidence of registered cot deaths has decreased from $1.04 / 1000$ live births in
\end{abstract}

After 1971, increasing numbers of Dutch children were placed in a prone position in bed. In the same period (1972-5) the incidence of sudden unexpected death in infancy more than doubled. ${ }^{1}$ On 21 October 1987, a medical lecture was given on the statistically highly significant association between cot death and a prone sleeping position. This was the result of our first Dutch study with unmatched and matched reference infants, indicating that for infants the prone sleeping position was potentially dangerous. ${ }^{2-4}$ The next day the Nationale Kruisvereniging (at the time the organisation which regulated the Dutch well baby clinics and maternity home care) recognised the importance of this issue and a policy of nonprone sleeping positions for infants was recommended. What was the impact of this advice in daily baby care in the following years, and to what extent has the incidence of cot death changed in the Netherlands since 1987 ?

Table 1 Prevalence of a prone sleeping position in infancy (sometimes or always put to sleep prone) by age and sex in six surveys on sleeping positions in the Netherlands 1982-92

\begin{tabular}{|c|c|c|c|c|}
\hline Source of data & $\begin{array}{l}\text { Year of } \\
\text { birth }\end{array}$ & $\begin{array}{l}\text { Age } \\
\text { (days) }\end{array}$ & $\begin{array}{l}\text { No (\%) } \\
\text { boys prone }\end{array}$ & $\begin{array}{l}\text { No (\%) } \\
\text { girls prone }\end{array}$ \\
\hline $\begin{array}{l}17 \text { Well baby clinics, birth weight } \\
>2500 \mathrm{~g}^{3}\end{array}$ & $1982-7$ & $30-240$ & $174(64 \cdot 4)$ & $146(58 \cdot 2)$ \\
\hline $\begin{array}{l}\text { National survey in municipalities with } \\
>20000 \text { inhabitants }\end{array}$ & $1985-7$ & $0-180$ & $336(67 \cdot 0)$ & $221(57 \cdot 5)$ \\
\hline Three midwife practices in Zuid-Holland ${ }^{7}$ & 1987 & $\begin{array}{r}0-150 \\
151-270\end{array}$ & $\begin{array}{l}145(60 \cdot 0) \\
154(65 \cdot 6)\end{array}$ & $\begin{array}{l}142(47 \cdot 2) \\
149(49 \cdot 0)\end{array}$ \\
\hline 112 Well baby clinics in 10 provinces $^{4}$ & 1988 & $\begin{array}{r}0-150 \\
151-300\end{array}$ & $\begin{array}{l}537(30 \cdot 0) \\
368(29 \cdot 6)\end{array}$ & $\begin{array}{l}490(22 \cdot 4) \\
368(25 \cdot 3)\end{array}$ \\
\hline 83 Well baby clinics in all 12 provinces $^{5}$ & 1990 & $\begin{array}{c}0 \cdot 150 \\
151-300\end{array}$ & $\begin{array}{l}535(16 \cdot 3) \\
325(22 \cdot 8)\end{array}$ & $\begin{array}{l}501(12 \cdot 4) \\
349(16 \cdot 6)\end{array}$ \\
\hline 137 Well baby clinics in all 12 provinces $^{6}$ & 1992 & $\begin{array}{c}31-60 \\
61-150 \\
151-270\end{array}$ & $\begin{array}{l}902(7 \cdot 0) \\
434(9 \cdot 0) \\
649(14 \cdot 6)\end{array}$ & $\begin{array}{l}875(6 \cdot 3) \\
424(9 \cdot 0) \\
604(10 \cdot 1)\end{array}$ \\
\hline
\end{tabular}

SEX

In all six surveys more boys than girls were placed prone always or sometimes for sleep. This difference was evident over the whole period of nine months. The background of this curious phenomenon is unknown.

AGE

Generally there was a slight increase in the prone position with age. The prevalence was higher after the first 5 to 6 months than before this age. 
Table 2 Infants (age 0-9 months) always or sometimes put to sleep in a prone position versus birth order and sex; national surveys of sleeping positions in the Netherlands in 1985-7, 1988, 1990, and 1992

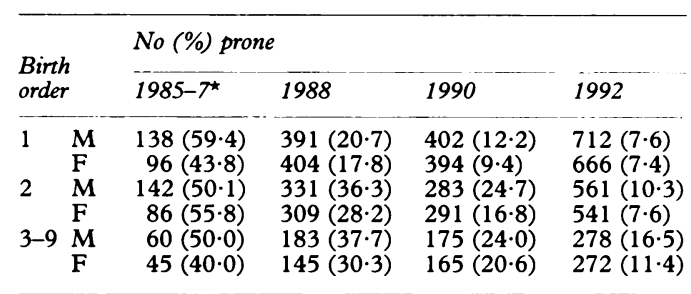

${ }^{\star}$ In the third month of life.

Table 3 Infants (age 0-9 months) always or sometimes put to sleep in a prone position and birth weight below 2500 g: national surveys of sleeping positions in the Netherlands in 1985-7, 1988, 1990, and 1992

\begin{tabular}{|c|c|c|c|c|}
\hline \multirow{2}{*}{$\begin{array}{l}\text { Birth } \\
\text { weight } \\
\text { (g) }\end{array}$} & \multicolumn{3}{|c|}{ No (\%) prone } & \multirow[b]{2}{*}{1992} \\
\hline & $1985-7$ & 1988 & 1990 & \\
\hline $\begin{array}{l}<2500 \\
\geqslant 2500\end{array}$ & $\begin{array}{r}22(77 \cdot 3) \\
531(62 \cdot 5)\end{array}$ & $\begin{array}{r}75(37 \cdot 3) \\
1688(26 \cdot 4)\end{array}$ & $\begin{array}{r}77(19.5) \\
1636(16.3)\end{array}$ & $\begin{array}{c}181(10 \cdot 5) \\
2849(9 \cdot 1)\end{array}$ \\
\hline
\end{tabular}

DECREASE AFTER OCTOBER 1987

After October 1987 the prevalence of the prone sleeping position in infancy decreased all over the country. Roughly speaking, the mean prevalence decreased from $60 \%$ in $1985-7$ to $27 \%$ in $1988,16 \%$ in 1990 , and $10 \%$ in 1992 . In the period 1985-90 the percentage of young infants (age 0-90 days) put to sleep on their side increased markedly.

BIRTH ORDER

In the last four national surveys, birth order was noted. After 1987 a marked difference was found for both sexes in the prevalence of the prone position between first born infants and infants with a higher birth order. This finding reflected the greater acceptance of the new advice by parents of first born infants than by parents who already had children. In 1992 the difference in sleeping position by birth order had shifted from second born infants to third born infants, which indicates that this difference will disappear in the future.

BIRTH WEIGHT

A low birth weight was associated with a higher prevalence of being placed in a prone sleeping position. This finding was in keeping with the long maintained practice of Dutch neonatologists to continue a prone position for preterm infants after the first weeks of life.

\section{Incidence of cot death}

DECREASE AFTER OCTOBER 1987

The incidence of registered postperinatal cot death/sudden infant death syndrome (SIDS) (ICD 798.0) decreased from 1.04/1000 live births in 1986 to 0.44 in 1991 (table 4 ) ${ }^{89}$ In the same period the numbers of several related registered causes of death also decreased consistently. Although there was some steady increase in the number of live births the total number of registered deaths in the categories acute respiratory infections (ICD 460-6), pneumonia/influenza (ICD 480-7), and bronchitis/emphysema/asthma (ICD 490-6) more than halved. This reflects the World Health Organisation classification rules: when a death is classifiable under ICD codes 780-99, which include cot death, and a disorder classifiable elsewhere is also reported, the latter takes precedence and the cause of death is reselected. Owing to this practice a number of cot death cases are hidden in other categories, including the respiratory infections. The same holds true for inhalation and ingestion of food (ICD E911) and accidental mechanical suffocation in bed or cradle (ICD E913.0). Consequently, the real decrease in cot deaths is greater than reflected by the classification 'cot death/SIDS'. Therefore, the decrease of postperinatal mortality from 3.9 in $1985-6$ to 2.7 in 1991 (after a long period of only minor changes in this death rate) appears to be mainly caused by this extended decrease in sudden unexpected death.

SEX

As in nearly all studies on cot death, in the Netherlands more male than female infants are affected. In these years the sex ratio varied between $1 \cdot 2(1985-6)$ and $1.6(1988-9)$.

AGE

As in all statistics of cot death, most cases occurred in the first six months of life, especially in the second, third, and fourth

Table 4 Number of deaths in the Netherlands of infants aged 1 week to 1 year in each mortality category (ICD 9th revision), 1985-91 (Netherlands Central Bureau of Statistics, Voorburg) ${ }^{8} 9$

\begin{tabular}{|c|c|c|c|c|c|c|c|c|}
\hline Code & Cause of death & 1985 & 1986 & 1987 & 1988 & 1989 & 1990 & 1991 \\
\hline $460-6$ & Acute respiratory infections & 15 & 19 & 7 & 7 & 10 & 9 & 1 \\
\hline $480-7$ & Pneumonia and influenza & 24 & 28 & 24 & 14 & 13 & 8 & 12 \\
\hline $490-6$ & Bronchitis, emphysema, asthma & 3 & 5 & 3 & 1 & 3 & 0 & 3 \\
\hline $780-9$ & Symptoms & 1 & 0 & 2 & 0 & 1 & 1 & 2 \\
\hline $798 \cdot 0$ & Cot death/SIDS & 191 & 191 & 170 & 108 & 133 & 110 & $8 \overline{8}$ \\
\hline 799 & Other ill defined and unknown causes & 27 & 21 & 25 & 15 & 14 & 36 & 24 \\
\hline E911 & Inhalation and ingestion of food & 14 & 11 & 9 & 6 & 2 & 10 & 5 \\
\hline E913.0 & $\begin{array}{l}\text { Accidental mechanical suffocation } \\
\text { in bed or cradle }\end{array}$ & 10 & 12 & 7 & 6 & 2 & 8 & 5 \\
\hline E960-9 & Infanticide & 3 & 3 & 2 & 5 & 0 & 3 & 0 \\
\hline \multirow{2}{*}{\multicolumn{2}{|c|}{$\begin{array}{l}\text { Live births }(\times 1000) \\
\text { Infant deaths }(1 \text { week to }<1 \text { year }) \\
\text { Cot death/SIDS per } 1000 \text { live births } \\
\quad(1 \text { week to }<1 \text { year })\end{array}$}} & $\begin{array}{l}178 \\
726\end{array}$ & $\begin{array}{l}185 \\
687\end{array}$ & $\begin{array}{l}187 \\
676\end{array}$ & $\begin{array}{l}187 \\
596\end{array}$ & $\begin{array}{l}189 \\
558\end{array}$ & $\begin{array}{l}198 \\
621\end{array}$ & $\begin{array}{l}199 \\
544\end{array}$ \\
\hline & & 1.07 & 1.04 & 0.91 & 0.58 & $0 \cdot 70$ & 0.56 & 0.44 \\
\hline \multirow{3}{*}{\multicolumn{2}{|c|}{$\begin{array}{l}\text { Postperinatal mortality } \\
\text { First week mortality } \\
\text { Infant mortality }\end{array}$}} & $4 \cdot 08$ & $3 \cdot 74$ & $3 \cdot 66$ & $3 \cdot 18$ & $2 \cdot 94$ & $3 \cdot 14$ & $2 \cdot 74$ \\
\hline & & 3.9 & $4 \cdot 0$ & $3 \cdot 9$ & $3 \cdot 6$ & $3 \cdot 9$ & $4 \cdot 0$ & $3 \cdot 8$ \\
\hline & & $8 \cdot 0$ & $7 \cdot 7$ & $7 \cdot 6$ & $6 \cdot 8$ & $6 \cdot 8$ & $7 \cdot 1$ & 6.5 \\
\hline
\end{tabular}


Table 5 Incidence of cot death/SIDS (ICD-9 798.0) in the first and second half of the first year for boys and girls in the Netherlands 1985-91 (Central Bureau of Statistics, Voorburg)

\begin{tabular}{|c|c|c|c|}
\hline & \multirow{2}{*}{$\begin{array}{l}\text { No of } \\
\text { live births }\end{array}$} & \multicolumn{2}{|c|}{ No of cot deaths/SIDS (rates per 100000$)[\%]^{\star}$} \\
\hline & & $0-5$ months & 6-11 months \\
\hline $\begin{array}{l}\text { Boys } \\
1985-6 \\
1987 \\
1988-9 \\
1990 \\
1991\end{array}$ & $\begin{array}{r}184880 \\
95819 \\
191774 \\
101561 \\
101581\end{array}$ & $\begin{array}{r}174(94 \cdot 1)[100] \\
81(84 \cdot 5)[90] \\
112(58 \cdot 4)[62] \\
49(51 \cdot 2)[51] \\
38(37 \cdot 4)[40]\end{array}$ & $\begin{array}{l}44(23 \cdot 8)[100] \\
21(21 \cdot 9)[92] \\
39(20 \cdot 3)[85] \\
19(18 \cdot 7)[79] \\
16(15 \cdot 8)[66]\end{array}$ \\
\hline $\begin{array}{l}\text { Girls } \\
1985-6 \\
1987 \\
1988-9 \\
1990 \\
1991\end{array}$ & $\begin{array}{r}177769 \\
90848 \\
183852 \\
96404 \\
97084\end{array}$ & $\begin{array}{c}132(74 \cdot 2)[100] \\
55(60 \cdot 5)[82] \\
61(33 \cdot 2)[45] \\
30(31 \cdot 1)[42] \\
27(27 \cdot 8)[37]\end{array}$ & $\begin{array}{l}45(25 \cdot 3)[100] \\
15(16 \cdot 5)[65] \\
29(15 \cdot 8)[62] \\
14(14 \cdot 5)[57] \\
12(12 \cdot 4)[49]\end{array}$ \\
\hline $\begin{array}{c}\text { Boys and girls } \\
1985-6 \\
1987 \\
1988-9 \\
1990 \\
1991\end{array}$ & $\begin{array}{l}362649 \\
186667 \\
375626 \\
197965 \\
198630\end{array}$ & $\begin{array}{c}306(84 \cdot 4)[100] \\
136(72 \cdot 8)[86] \\
173(46 \cdot 1)[55] \\
79(39 \cdot 9)[47] \\
65(32 \cdot 7)[39]\end{array}$ & $\begin{array}{l}89(24 \cdot 5)[100] \\
36(19 \cdot 3)[79] \\
68(18 \cdot 1)[74] \\
33(16 \cdot 7)[68] \\
28(14 \cdot 1)[58]\end{array}$ \\
\hline
\end{tabular}

^Percentage relative to $1985-6$.

month. It is in this age group that the recent decrease was most pronounced. Compared with the mean incidences of cot death in 1985-6 the decrease in 1991 in the first half year of life was $61 \%$, whereas the incidence in the second half year of life only decreased by $42 \%$ Netherlands Central Bureau of Statistics) (table 5).

It should be remembered that cot death (notified as sudden death) is not limited to the first year of life, but also occurs in the second year (ICD 798.1). In the Netherlands this accounts for about $5 \%$ of all cot deaths of infants in the first two years (Netherlands Central Bureau of Statistics ${ }^{9}$ ).

\section{BIRTH ORDER}

Most studies on cot death report the phenomenon that first born infants show a lower incidence of cot death than infants with a higher birth order. The same is true for the Netherlands: in recent studies of cot death in the Netherlands over the period 1985-91 only $36 \%$ of 308 cot death infants were first born, in contrast with $44 \%$ in the total population. 410

\section{BIRTH WEIGHT}

In the same Dutch studies the birth weight of $46(15 \%)$ of the 308 cot death infants was less than $2500 \mathrm{~g}$, in contrast with $6 \%$ of all infants born in the Netherlands in these years. In the case control study a low birth weight increased the risk of cot death, all other factors being equal, by about 1.5 times for every $500 \mathrm{~g}$ less weight. ${ }^{4}$

\section{Discussion}

The preponderance of boys put to sleep in a prone position, reported in all six surveys of sleeping positions in the Netherlands, is an unexplained surprise. Is there any hidden reason, any psychological ground for such discriminating behaviour of care givers? We are unaware of comparable data in other countries.

The influence of a higher birth rank number on a prone sleeping position is only seen after
1987 and thus could be ascribed to parents' 'previous practice': parents who had already given care to one or more infants who were usually put to sleep in a prone position are less inclined to put their next infant in a non-prone sleeping position than parents with their first infant, who are more open to new advice on baby care.

The change in sleeping habits in the Netherlands is not simple to explain. Most professionals (paediatricians and nurses) were reluctant to accept the statistical conclusions; criticism was published in a report of the Dutch Paediatric Association. The policy of the Nationale Kruisvereniging, however, was a good stimulus, supported by the experience of the anonymous collective of grandmothers used to a non-prone position, and resulted in a marked, progressive decrease in prone sleeping position in infancy. Eventually many doctors were more impressed by the decrease in the incidence of cot death (though there was only supportive evidence) than by a statistical analysis of epidemiological data.

As with traffic accidents, most cases of sudden and unexpected death during a sleep period in infancy are caused by a combination of factors. External factors which have been clearly shown to be potential causal factors are a prone sleeping position, ${ }^{11} 12$ maternal smoking, ${ }^{13} 14$ respiratory infections, use of duvets and overheating, ${ }^{15} 16$ the drug promethazine, ${ }^{17}$ parental intake of alcohol combined with overlying, ${ }^{18}$ and maternal cocaine and heroin abuse. ${ }^{19}$ Other possible factors include lack of supervision, ${ }^{10} 20$ abnormal stress and fatigue, and intestinal infection by toxigenic Escherichia coli ${ }^{21}$ or Clostridium botulinum. ${ }^{22}$ Some internal factors and prenatal or perinatal influences are also suspected. Among the potential causal factors, however, the relative risk of a prone sleeping position is relatively high (between about three and six).

A simultaneous decrease in the prevalence of a prone sleeping position and the incidence of cot death is now seen in all regions and countries with sufficient experience. It must be stressed, however, that a simultaneous decrease in two phenomena is not proof of a causal relation, but at most a welcome confirmation. In support of this, however, over the period 1985-91 none of the other potential risk factors (passive smoking, respiratory infections, use of duvets and overheating, promethazine, or lack of supervision) changed favourably in the Netherlands.

As the Dutch national campaign to discourage a prone sleeping position started in October 1987, a nationwide evaluation over the first four years was possible (in July 1991 Australia, in November 1991 the United Kingdom, and in May 1992 the USA followed the Dutch lead). When the national surveys of sleep position and the statistics of cot death in the years 1985 up to and including 1991 are compared, the following conclusions can be drawn.

Firstly, the continuing decrease in the incidence of cot death parallels the continuing decrease in the prone sleeping position as 
shown in a series of national surveys. Secondly, the incidence of cot death decreased more for infants in the first six months than for older infants, an anticipated difference as older infants often chose their own sleeping position and the parental choice of a non-prone position has less influence. Thirdly, the consistent, remarkable observation that in the Netherlands more boys than girls are placed prone to sleep 'explains' half of the high sex ratio for cot death. Fourthly, the consistent finding that over the period 1987-92 more higher birth order infants than first born infants were placed prone to sleep suggests that this aspect of baby care might have enhanced the generally stated relatively high incidence of cot death for these higher birth order infants; their higher risk of respiratory infections is probably of additional influence. Finally, the higher prevalence of a prone sleeping position among low birthweight infants after discharge from hospital probably has some additional unfavourable impact on their high incidence of cot death.

Whether a further decrease in the use of the prone sleeping position will be followed by a further decrease in the incidence of cot death in the Netherlands remains to be seen.

1 Engelberts AC, Jonge GA de. Choice of sleeping position for infants: possible association with cot death. Arch Dis Child 1990; 65: 462-7.

2 Jonge GA de. Naar preventie van wiegedood. Medisch Contact 1987; 42: 1562 .

3 Jonge GA de, Engelberts AC, Koomen-Liefting AJM, Kostense PJ. Cot death and prone sleeping position in the Netherlands. BMf 1989; 298: 722 .

4 Engelberts AC. Cot death in the Netherlands; an epidemiological study. Amsterdam: VU University Press, 1991.

5 Sprij AJ, Drewes JBJ, Engelberts AC, Jonge GA de. Slaaphouding zuigelingen najaar 1988. Tijdschrift voor feugdgezondheidszorg 1989; 21: 53-7.
6 Sprij AJ, Jonge GA de. Slaaphouding zuigelingen 19881990. Tijdschrift voor feugdgezondheidszorg 1991; 23: $38-40$.

7 Burgmeijer RJF, Jonge GA de. Slaaphouding zuigelingen 1988-1992. Tijdschrift voor feugdgezondheidszorg 1993; 25: 35-8.

8 Dam JMC van, Herrewaarden MJC van, Engelberts AC, Jonge GA de. Verandering in de slaaphouding van zuigelingen. Tijdschrift voor feugdgezondheidszorg 1989; 21: $22-4$.

9 Netherlands Central Bureau of Statistics (CBS) Overledenen naar doodsoorzaak, leefiijd en geslacht in het jaar Overledenen naar doodsoorzaak, leefijd en geslacht in het jaar
1985 (serie A1). Voorburg: CBS, 1987. (Yearly edition, up 1985 (serie A1). Voorburg: CBS, 198
to 1991 , edition 1993, inclusive.)

10 Jonge GA de, Kostense PJ, Pieterson I. Prävention des plötzlichen Kindstodes. In: Trowitzsch E, Schütter B, Andler W (eds). Der plötzliche Kindstod: Prävention des SID. Berlin: Acron, 1993: 90-104.

11 Guntheroth WG, Spiers PS. Sleeping prone and the risk of sudden infant death syndrome. $\mathscr{F} A M A$ 1992; 267: 2359-62.

12 American Academy of Pediatrics Task Force on Infant Positioning and SIDS. Positioning and SIDS. Pediatrics 1992; 89: 1120-6.

13 Haglund B, Cnattingius S. Cigarette smoking as a risk factor for sudden infant death syndrome: a population factor for sudden infant death syndrome: a popula
based study. Am $\mathcal{F}$ Public Health 1990; 80: 29-32.

14 Schoendorf KC, Kiely JL. Relationship of sudden infant death syndrome to maternal smoking during and after pregnancy. Pediatrics 1992; 90: 905-8

15 Gilbert R, Rudd P, Berry PJ, et al. Combined effect of infection and heavy wrapping on the risk of sudden unexpected infant death. Arch Dis Child 1992; 67: 171-7.

16 Ponsonby A-L, Dwyer T, Gibbons LE, Cochrane JA, Jones ME, McCall MJ. Thermal environment and sudden infant death syndrome: case-control study. BMF 1992; 304: 277-82.

17 Jonge GA de. Wiegedood en promethazine. Ned Tijdschr Geneeskd 1992; 136: 1945-8.

18 Rintahaka P. Sudden infant death syndrome in Finland in 1969-80. Helsinki: Publication of the National Board of Health, 1985.

19 Davidson Ward SL, Bautista D, Chan L, et al. Sudden infant death syndrome in infants of substance-abusing mothers. F Pediatr 1990; 117: 876-81.

20 Davies DP. Cot death in Hong Kong: a rare problem? Lancet 1985; ii: 1346-9.

21 Bettelheim KA, Goldwater PN, Pearce JL. Toxigenic Escherichia coli and sudden infant death syndrome. Scand Escherichia coli and sudden in

22 Arnon SS, Midura TF, Damus K, Wood RM, Chin J Intestinal infection and toxin production by Clostridium botulinum as a cause of sudden infant death syndrome. Lancet 1978; i: 1273-7. 